\title{
AKTIVITAS ANTIBAKTERI MINYAK ATSIRI DAUN PALA DARI BANYUMAS TERHADAP Staphylococcus aureus DAN Escherichia coli SERTA IDENTIFIKASI SENYAWA PENYUSUNNYA
}

\author{
Undri Rastuti $^{1}$, Senny Widyaningsih ${ }^{1}$, Dwi Kartika ${ }^{1}$, Dian Riana Ningsih ${ }^{1}$ \\ ${ }^{1}$ Program Studi Kimia Jurusan MIPA Fakultas Sains dan Teknik \\ Universitas Jenderal Soedirman \\ J1. Dr Soeparno Purwokerto Utara 53123
}

\begin{abstract}
ABSTRAK
Staphylococcus aureus dan Escherichia coli adalah bakteri yang dapat menyebabkan infeksi. Umumnya masyarakat dalam mengobati penyakit infeksi terhadap bakteri sering menggunakan antibiotik, namun apabila digunakan secara berlebihan dan kurang terarah dapat mengakibatkan terjadinya resistensi. Untuk mengatasinya diperlukan pencarian bahan alami sebagai alternatif pengobatan, salah satunya yaitu minyak atsiri daun pala. Penelitian ini bertujuan untuk mengetahui aktivitas antibakteri minyak atsiri daun pala dari Banyumas terhadap $S$. aereus dan $E$. coli serta mengidentifikasi senyawa penyusunnya. Minyak atsiri dari serbuk daun pala kering diisolasi menggunakan metode destilasi air. Minyak atsiri yang diperoleh diuji sifat fisik dan dilakukan identifikasi senyawa penyusunnya menggunakan GC-MS. Pengujian aktivitas antibakteri dilakukan dengan menggunakan metode difusi untuk mengetahui Konsentrasi Hambat Tumbuh Minimum (KHTM) terhadap S. aereus dan E. coli. Rendemen minyak atsiri daun pala yang diperoleh sebesar 1,34\%. Minyak atsiri ini berwarna kuning pucat, berbau khas minyak pala dengan indeks bias sebesar 1,4779 dan bobot jenis sebesar $0,8862 \mathrm{~g} / \mathrm{cm}^{3}$. Minyak atsiri daun pala diketahui memiliki 33 komponen kimia dan 5 komponen kimia terbesarnya adalah sabinene, terpinene-4-ol, $\alpha$ pinene, $\beta$-pinene, and $\beta$-phellandrene. Minyak atsiri daun pala terbukti memiliki aktivitas antibakteri terhadap $S$. aureus dengan KHTM pada konsentrasi minyak atsiri $3,125 \%$ menghasilkan zona hambat sebesar $16,81 \mathrm{~mm}$ dan terhadap E. coli dengan KHTM pada konsentrasi minyak atsiri $1 \%$ menghasilkan zona hambat sebesar 0,54 mm.
\end{abstract}

Kata kunci : daun pala, difusi, Escherichia coli, minyak atsiri, Staphylococcus aureus,

\section{ANTIBACTERIAL ACTIVITY OF NUTMEG LEAF ESSENTIAL OILS FROM BANYUMAS TOWARD Staphylococcus aureus AND Escherichiacoli, AND IDENTIFICATION OF THE COMPOUNDS}

\begin{abstract}
Staphylococcus aureus and Escherichia coli are bacteria that can cause infection. Generally people use antibiotics in treating bacteria infectious diseases, but when overused and less directional it can result resistance. It is necessary to look for the alternative treatment, such as natural product from the nutmeg leaf essential oils. This research aimed to know the antibacterial activity of nutmeg leaf essential oils from Banyumas toward S. aereus dan E. coli bacteria and identified the compounds. Essential
\end{abstract}


oil of dry nutmeg leaves was isolated using water distillation. The physical properties of essential oil were tested and the compounds were identified using GC-MS. Antibacterial activity assay was performed using diffusion method to determine Minimum Inhibitor Concentration Grows (MICG) against S. aureus and E. coli. The yield of nutmeg leaf essential oils was $1.34 \%$. The colors was pale yellow with the smell of typical nutmeg oil, the refractive index was 1.4779 , and the density was $0.8862 \mathrm{~g} / \mathrm{cm}^{3}$. Essential oil of nutmeg leaves had 33 chemical components and the biggest five chemical components were sabinene, terpinene-4-ol, $\alpha$-pinene, $\beta$-pinene, and $\beta$-phellandrene. Essential oil of nutmeg leaves shown to have antibacterial activity against $S$. aureus with Minimum Inhibitor Concentration Grows (MICG) at 3.125\% concentration of essential oil produced $16.81 \mathrm{~mm}$ of inhibition zone and the E. coli with Minimum Inhibitor Concentration Grows (MICG) at $1 \%$ concentration of essential oil produced $0.54 \mathrm{~mm}$ of inhibition zone.

Keywords : diffusion, Escherichia coli, essential oil, nutmeg leaf, , Staphylococcus aureus,

\section{PENDAHULUAN}

Tanaman pala merupakan tanaman asli Indonesia. Pala dikenal sebagai tanaman rempah yang memiliki nilai ekonomis dan multiguna karena setiap bagian tanaman dapat dimanfaatkan dalam berbagai industri. Minyak atsiri yang berasal dari biji dan fuli pala banyak digunakan untuk industri obat-obatan, parfum dan kosmetik. Mengacu pada Kurniawati (1998) penelitian tentang minyak atsiri saat ini banyak diarahkan untuk memanfaatkannya sebagai antimikroba penyakit yang disebabkan oleh bakteri atau jamur.

$S$. aureus merupakan penyebab infeksi piogenik pada manusia dan paling sering terjadi. $S$ aureus menyebabkan kasus sepsis pada luka bedah, pada unit kebidanan menyebabkan abses payudara, mata lengket, dan lesi-lesi kulit pada bayi. $E$ coli adalah salah satu bakteri yang dapat menyebabkan infeksi saluran kencing yang merupakan infeksi terbanyak, gastroenteritis, meningitis pada bayi, peritonitis, infeksi luka, kolesistitis, dan syok bakteremia karena masuknya organisme ke dalam darah dari uretra (Gibson, 1996).
Umumnya masyarakat dalam mengobati penyakit infeksi terhadap bakteri sering menggunakan antibiotik seperti tetrasiklin, ampisilin atau antibiotika jenis lainnya yang dengan mudah dapat diperoleh. Pemakaian antibiotik secara berlebihan dan kurang terarah dapat mengakibatkan terjadinya resistensi. Timbulnya resistensi pada beberapa antibiotik tertentu dapat menyebabkan kegagalan dalam pengobatan berbagai jenis penyakit infeksi, sehingga untuk mengatasinya diperlukan pencarian bahan alami sebagai alternatif pengobatan (Josodiwondo dkk., 1996).

Minyak atsiri merupakan salah satu bahan alami yang dapat digunakan untuk mengobati infeksi terhadap bakteri. Oleh karena itu, dalam penelitian ini dilakukan isolasi minyak atsiri dari daun pala dari Banyumas dengan destilasi air, kemudian dianalisis komponen-komponen kimia minyak atsiri daging buah pala tersebut menggunakan GC-MS, dandiuji aktivitas antibakteri terhadap $S$. Aureus dan E. coli dengan mengetahui Konsentrasi Hambat Tumbuh Minimum (KHTM) terhadap S. Aureus dan E. coli. 


\section{METODE PENELITIAN Waktu dan Tempat Penelitian}

Penelitian ini dilaksanakan selama tiga bulan dari bulan November 2012 sampai dengan bulan Januari 2013 di Laboratorium PT Indesso Aroma dan Laboratorium Biokimia Jurusan MIPA Fakultas Sains dan Teknik. Determinasi daun pala dilaksanakan di Laboratorium Taksonomi Fakultas Biologi Universitas Jenderal Soedirman Purwokerto.

\section{Alat dan Bahan Penelitian Alat penelitian}

Alat yang diperlukan dalam penelitian ini adalah alat-alat gelas, botol gelap, termometer, seperangkat alat destilasi air, alat GCMS Agilent 7890A $M S D$ 5975C, neraca digital, Digital Refractometer, jarum ose, drugalsky, crock bor, Digital Density Meter DMA 5000, autoklaf, shaker incubator, filler, pipet ukur, hot plate, pipet mikro otomatis, wrapping, kapas, kain kassa, cawan petri, inkubator, dan jangka sorong.

\section{Bahan}

Bahan yang diperlukan dalam penelitian ini adalah daun pala, bakteri $S$. aureus, E.Coli, Nutrient Agar (NA), Nutrient Broth (NB), tetrasiklin, etanol, Pepton Yeast Agar (PYG), alkohol 70\%, akuades, dan kertas saring.

\section{Prosedur Penelitian \\ Determinasi bahan penelitian}

Bahan penelitian berupa batang, daun, buah dan bunga pala dari Banyumas dideterminasi terlebih dahulu jenisnya berdasarkan data pustaka.

\section{Preparasi sampel}

Daun pala segar dibersihkan dari kotoran yang melekat dan dicuci dengan air bersih. Setelah itu, daun pala dikeringkan pada suhu kamar. Daun pala yang sudah kering selanjutnya diblender.

\section{Isolasi minyak atsiri}

Sebanyak 200 gram serbuk daun pala didestilasi dengan etanol. Minyak daun pala yang diperoleh dihitung jumlah rendemennya.

\section{Penentuan sifat-sifat fisik}

Penentuan sifat fisik dari minyak atsiri meliputi: warna, bau, bobot jenis, dan indeks bias. Bobot jenis ditetapkan dengan menggunakan alat Digital Density Meter DMA 5000, sedangkan indeks bias minyak daun pala diukur menggunakan Digital Refractometer. Hasil yang diperoleh dibandingkan dengan pembanding SNI 06-2388-2006.

\section{Analisis komposisi senyawa kimia penyusun minyak atsiri}

Komposisi senyawa kimia dari minyak atsiri daun pala dianalisis menggunakan alat GC-MS Agilent $7890 A$ MSD 5975C.

\section{Uji aktivitas antibakteri dengan metode difusi (Bintang, 1993)}

Sebanyak satu ose bakteri dari stok biakan diambil lalu diinkubasi di dalam 10 mL medium cair NB selama 20 jam pada suhu $37 \quad{ }^{\circ} \mathrm{C}$ dan sambil dikocok menggunakan shaker incubator. Selain itu, dituangkan sebanyak $15 \mathrm{~mL}$ medium PYG pada suhu $\pm 40{ }^{\circ} \mathrm{C}$ ke dalam cawan petri steril. Selanjutnya didiamkan pada suhu kamar sampai medium agar memadat. Sejumlah biakan bakteri dalam medium cair NB diambil dan disebarkan di dalam medium PYG berdasarkan hasil absorbannya pada panjang gelombang $600 \mathrm{~nm}$. Jika nilai absorbansinya kurang atau sama dengan 0,5 maka diambil 100 $\mu \mathrm{L}$ biakan bakteri, sedangkan jika 0,6-1,0 diambil $50 \mu \mathrm{L}$. Suspensi bakteri uji pada medium PYG distreak secara spread plate dengan menggunakan drugalsky, kemudian didiamkan hingga kering selama 15 menit pada suhu kamar. Setelah 
kering agar dilubangi dengan diameter \pm 8 mm menggunakan crock bor. Sampel dan larutan kontrol dimasukkan ke dalam lubang tersebut lalu diinkubasi pada suhu $37^{\circ} \mathrm{C}$ selama 20 jam. Zona hambat yang terlihat bening di sekeliling lubang, menandakan adanya aktivitas antibakteri. Zona hambat yang terbentuk diukur menggunakan jangka sorong.

\section{Pengujian Konsentrasi Hambat Tumbuh Minimum (KHTM)}

Setelah diketahui minyak atsiri daging buah pala mempunyai aktivitas antibakteri, selanjutnya ditentukanKHTM pada minyak atsiri terhadap bakteri uji.KHTM digunakan untuk mengetahui konsentrasi minimal dari suatu larutan antimikroba terhadap pertumbuhan mikroba tertentu. Variasi konsentrasi yang digunakan untuk menentukan KHTM pada penelitian ini yaitu $100 \%, 50 \%, 25 \%$, $12,5 \%, 6,25 \%, 3,125 \%, 1 \%$, dan 0,5 $\%(\mathrm{v} / \mathrm{v})$. Uji terhadap etanol dilakukan sebagai kontrol pelarut. Masing-masing konsentrasi diuji dengan memasukkan sebanyak $50 \mu \mathrm{L}$ ke lubang medium PYG yang telah diinokulasi dengan bakteri uji. Setelah itu diinkubasi pada suhu $37{ }^{\circ} \mathrm{C}$ selama 20 jam. Aktivitas antibakterinya diperoleh dengan mengukur zona hambat yang terlihat bening di sekeliling lubang sampel dengan menggunakan jangka sorong.

\section{Analisis data}

Data penelitian hasil uji aktivitas antibakteri dianalisis secara statistik dengan ANOVA one way dengan menggunakan program SPSS 12,0 (Santoso, 2001) bila terdapat perbedaan atau pengaruh pada tiap perlakuan dilanjutkan dengan uji Duncan dengan taraf kepercayaan 0,05 persen untuk melihat perlakuan hasil tertinggi.

\section{Determinasi bahan penelitian}

Determinasi tanaman pala dilakukan di Laboratorium Taksonomi Tumbuhan Fakultas Biologi Universitas Jenderal Soedirman. Hasil determinasi tanaman menunjukkan bahwa tanaman yang digunakan untuk penelitian adalah Myristica fragrans Houtt.

\section{Preparasi sampel}

Daun pala yang digunakan untuk penelitian dikumpulkan dari Desa Kemawi, Kecamatan Somagede, Kabupaten Banyumas. Daging buah pala dicuci sampai bersih agar kotoran-kotoran seperti debu yang menempel dapat hilang kemudian dipotong kecil-kecil untuk membuka kelenjar minyak sebanyak mungkin, sehingga minyak dapat dengan mudah diuapkan (Guenther, 1987). Daun pala yang telah dipotong-potong dikeringkan di bawah sinar matahari secara tidak langsung dengan cara menutup daun pala yang dikeringkan dengan kain hitam untuk menghindari penguapan terlalu cepat, menghindari kontak langsung dengan pancaran sinar ultraviolet dan menghindari rusaknya bahan-bahan yang mudah teroksidasi oleh sinar matahari.

\section{Isolasi minyak atsiri}

Isolasi minyak atsiri dari daun pala pada penelitian ini menggunakan destilasi air. Jika disuling dengan cara lain, misalnya melalui penyulingan dengan uap, bahan akan merekat dan membentuk gumpalan besar yang kompak sehingga uap tidak bisa berpenetrasi ke dalam bahan (Lutony dan Rahmayati, 2002).

Serbuk daun pala yang didestilasi menghasilkan minyak atsiri dengan rendemen yang diperoleh adalah $1,72 \%$. 
Perbandingan mutu minyak atsiri daun pala dengan SNI 06-2388-2006 dapat dilihat pada Tabel 1.

\section{Analisis komposisi senyawa kimia penyusun minyak atsiri}

Kromatogram GC menunjukkan adanya 33 puncak. Lima komponen kimia terbesarnya dari hasil GC MS adalah sabinene, terpinene-4-ol, $\alpha$-pinene, $\beta$ pinene, $\operatorname{dan} \beta$-phellandrene, Gambar kromatogram dapat dilihat pada Gambar 1.

\section{Uji aktivitas antibakteri dengan metode difusi (Bintang, 1993)}

Hasil uji menggunakan metode difusi dari minyak atsiri daun pala dengan konsentrasi $25 \%$, tetrasiklin $\mathrm{HCl} 25 \%$, dan etanol positif menghambat pertumbuhan $S$. aureus dan E. coli yang ditandai dengan adanya zona bening di sekitar lubang sampel, sedangkan aquades tidak memperlihatkan adanya zona bening di sekitar lubang sampel. Hal ini menunjukkan bahwa minyak atsiridaun pala pada konsentrasi $25 \%$, tetrasiklin $\mathrm{HCl}$ $25 \%$

Tabel 1. Mutu minyak atsiri

\begin{tabular}{|c|l|c|c|}
\hline No. & \multicolumn{1}{|c|}{ Parameter mutu } & $\begin{array}{c}\text { Standar mutu } \\
\text { SNI 06-2388-2006 } \\
\text { Tidak berwarna }- \text { kuning } \\
\text { pucat }\end{array}$ & Minyak atsiri daun pala \\
\hline 1. & Warna & Khas minyak pala & Khas minyak pala \\
\hline 2. & Bau & $1,4700-1,4970$ & 1,4779 \\
\hline 3. & Indeks bias $20{ }^{\circ} \mathrm{C}$ & $0,8800-0,9100$ & 0,8862 \\
\hline 4. & $\begin{array}{l}\text { Bobot jenis } 20{ }^{\circ} \mathrm{C} \\
(\mathrm{g} / \mathrm{mL})\end{array}$ & \multicolumn{2}{c}{} \\
\hline
\end{tabular}

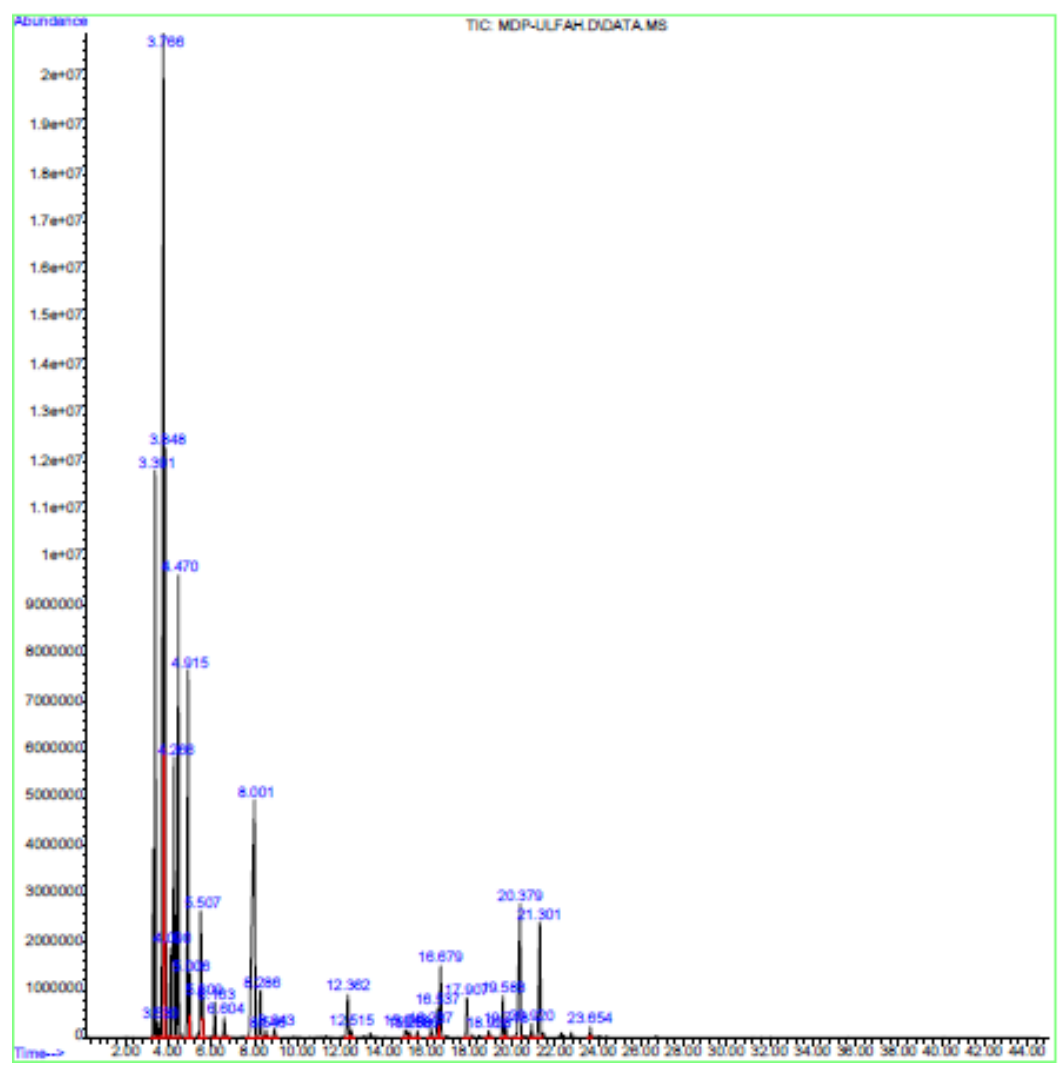

Gambar 1. Kromatogram GC MS Minyak atsiri daun Pala 
dan etanol mampu menghambat pertumbuhan bakteri $S$. aureus dan E. coli. Zona hambat minyak atsiri daun pala 25 $\%$, tetrasiklin $\mathrm{HCl} 25 \%$, dan etanol, untuk $S$. aureus berturut-turut sebesar $26,08 \mathrm{~mm}$, $28,75 \mathrm{~mm}$, dan $0 \mathrm{~mm}$, dan untuk $E$. coli $46,20 \mathrm{~mm}, 30,35 \mathrm{~mm}$, dan $0,89 \mathrm{~mm}$.

\section{Pengujian Konsentrasi Hambat Tumbuh Minimum (KHTM)}

Konsentrasi minyak atsiri daun pala yang digunakan dalam penentuan KHTM berkisar antara0,5 \%-100 \%.Grafik penentuan KHTM dari minyak atsiri daun pala terhadap $S$. aureus dan $E$. coli dapat dilihat pada Gambar 2 dan 3.

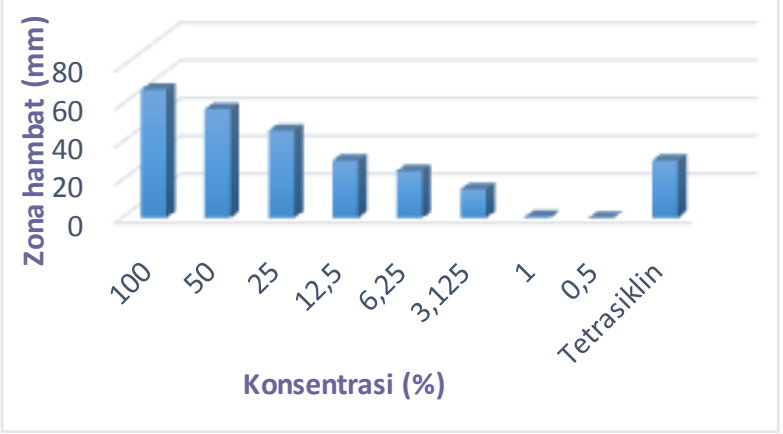

Gambar 2. KHTM terhadap S. aureus

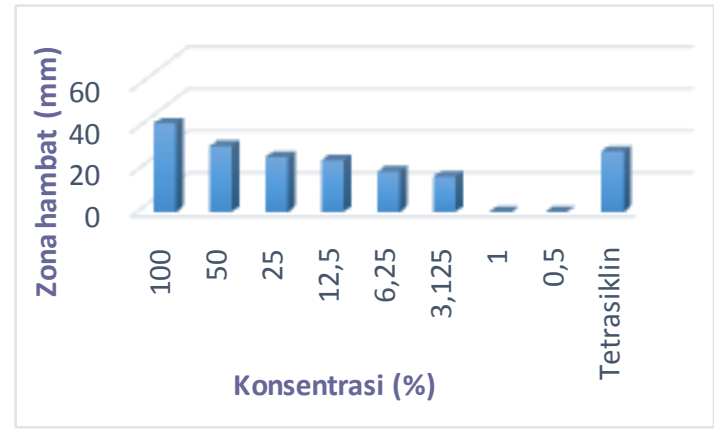

Gambar 3. KHTM E. coli

Berdasarkan hasil analisis ANOVA $(\alpha=0,05)$ minyak atsiri daun pala pada konsetrasi $0,5 \%$ - $100 \%$ memberikan nilai zona hambat yang berbeda nyata. Variasi konsentrasi yang digunakan berpengaruh pada zona hambat yang berbeda-beda. Perbedaan konsentrasi mempengaruhi luas zona hambat, konsentrasi minyak atsiri daun pala semakin rendah maka luas zona hambat juga semakin rendah, dikarenakan kandungan aktif yang terlarut dalam etanol juga semakin sedikit.

Tetrasiklin $\mathrm{HCl}$ merupakan kontrol positif yang digunakan pada penentuan KHTM, dimana tetrasiklin ini merupakan antibiotik standar terhadap daya hambat dari minyak atsiri daging buah pala. Mekanisme kerja tetrasiklin yaitu dengan menghambat sintesis protein pada ribosomnya. Terdapat dua proses masuknya tetrasiklin ke dalam bakteri gram negatif, pertama yang disebut difusi pasif melalui kanal hidrofilik. Kedua adalah sistem transport aktif. Setelah antibiotika tetrasiklin masuk ke dalam ribosom bakteri, maka antibiotika tetrasiklin berikatan dengan ribosom 30s dan menghalangi masuknya komplek tRNA-asam amino pada lokasi asam amino, sehingga bakteri tidak dapat berkembang biak (Gan dan Setiabudi, 1987).

Turunan fenol pada minyak atsiri daun pala berinteraksi dengan sel bakteri melalui proses adsorpsi yang melibatkan ikatan hidrogen. Pada kadar rendah terbentuk kompleks protein fenol dengan ikatan yang lemah dan segera mengalami peruraian, diikuti penetrasi fenol ke dalam sel dan menyebabkan presipitasi serta denaturasi protein. Pada kadar tinggi fenol menyebabkan koagulasi protein dan sel membran lisis (Parwata dan Dewi, 2008). Sementara itu, senyawa terpenoid merupakan salah satu senyawa yang terkandung dalam minyak atsiri daun pala seperti terpinen-4-ol.

\section{KESIMPULAN}

Berdasarkan hasil penelitian ini dapat disimpulkan bahwa:

1. Minyak atsiri daun pala dari Banyumas setelah diidentifikasi dengan GC-MS 
diketahui memiliki 33 komponen kimia dan 5 komponen kimia terbesarnya adalah sabinene, terpinene-4-ol, $\alpha$ pinene, $\beta$-pinene, dan $\beta$-phellandrene.

2. Konsentrasi Hambat Tumbuh Minimum (KHTM) minyak atsiri daun pala dari Banyumas terhadap S. aureus yaitu pada konsentrasi 3,125\% dengan zona hambat sebesar $16,81 \mathrm{~mm}$ dan untuk E. coli pada konsentrasi $1 \%$ dengan zona hambat sebesar $0,54 \mathrm{~mm}$.

\section{DAFTAR PUSTAKA}

Bintang, M., 1993, Studi Antimikroba dari Streptococcus lactis BCC 229, Disertasi, Program Doktor Institut Teknologi Bandung, Bandung.

Gan, V. H. S. and P. Setiabudi, 1987, Farmakologi dan Terapi, Fakultas Kedokteran Univeritas Indonesia, Jakarta.

Gibson, 1996, Perilaku Organisasi, Rineka Cipta, Jakarta.

Guenther, E., 1987, Minyak atsiri I, Universitas Indonesia Press, Jakarta.
Josodiwondo, S., U.C. Warsa, Soebiandrio, dan Soedarmono, 1996, Perkembangan Kuman terhadap Antimikroba Saat Ini, Majalah Kedokteran Indonesia, Ikatan Dokter Indonesia, Jakarta, 46(9): 467.

Kurniawati, I., 1998, Efektivitas Minyak Atsiri Cengkeh (Eugenia aromatic Kuntze) sebagai Bahan Antimikroba, Skripsi, Fakultas Biologi UGM, Yogyakarta.

Lutony, T. L. dan Y. Rahmayati, 2002, Produksi dan Perdagangan Minyak Atsiri, Penerbit Penebar Swadaya, Jakarta.

Parwata, I. M. O. A. dan P. F. S. Dewi, 2008, Isolasi dan Uji Aktivitas Antibakteri Atsiri dari Rimpang Lengkuas (Alpinia Galanga L), Jurnal, 2 (2), pp 4-10.

Santoso, S., 2001, Mengolah Data Statistik Secara Profesional dengan SPSS, PT. Media Komputindo Kelompok Gramedia, Jakarta. 